\title{
ANALISIS PAJAK REKLAME DI KABUPATEN PURWOREJO PERIODE 2012-2016
}

\author{
Arum Kusumaningdyah Adiati, Diessela Paravitasari, \\ Trisninik Ratih Wulandari \\ Fakultas Ekonomi dan Bisnis UNS Surakarta \\ Email :adiati_rk@yahoo.com
}

\begin{abstract}
ABSTRAK
Penelitian ini bertujuan untuk mengetahui perkembangan penerimaan pajak reklame di Kabupaten Purworejo selama tahun 2012 sampai dengan 2016. Perkembangan penerimaan pajak reklame ini selanjutnya digunakan sebagai dasar untuk mengidentifikasi berbagai kendala dalam pemungutan pajak reklame dan mengidentifikasi berbagai upaya untuk mengoptimalkan pajak reklame.

Penelitian ini merupakan studi kasus di Kabupaten Purworejo dan teknik pengumpulan data berupa observasi dan wawancara. Metode observasi dilakukan dengan pengamatan langsung di BPPKAD Kabupaten Purworejo, sedangkan wawancara dilakukan melalui tanya jawab dengan pegawai BPPKAD di Kabupaten Purworejo.

Hasil penelitian ini menunjukkan bahwa rata-rata tingkat kontribusi pajak reklame selama kurun waktu lima tahun mengalami peningkatan, meskipun untuk jenis reklame papan/ billboard/ videotron/ megatron dan jenis reklame kain selalu berada dalam kriteria sangat kurang rata-rata 0,609\% terhadap Pendapatan Asli Daerah (PAD) dan 0,620\% terhadap Pendapatan Pajak Daerah (PPD). Salah satu upaya untuk mengoptimalkan pajak reklame adalah dengan melakukan sosialisasi rutin dan merata kepada wajib pajak.
\end{abstract}

Kata kunci: Pajak Reklame, Pajak Daerah, Pendapatan Asli Daerah, Kontribusi Pajak.

\section{PENDAHULUAN}

\section{Latar Belakang Masalah}

Ketentuan mengenai otonomi daerah pada dasarnya bertujuan untuk meningkatkan daya guna dan hasil guna penyelenggaraan pemerintah daerah, terutama dalam pelaksanaan pembangunan dan pelayanan kepada masyarakat serta peningkatan pembinaan kesatuan politik dan kesatuan bangsa. Otonomi daerah di Indonesia dilaksanakan berdasarkan Undang-Undang Nomor 32 Tahun 2004 tentang Pemerintahan Daerah yang menyatakan bahwa,Otonomi Daerah adalah hak, wewenang, dan kewajiban daerah otonomi untuk mengatur dan 
mengurus sendiri urusan pemerintahan dan kepentingan masyarakat setempat sesuai dengan peraturan perundang-undangan yang berlaku.

Untuk pelaksanaan otonomi daerah tersebut, maka pemerintah daerah perlu memikirkan dana yang masuk untuk pembiayaan. Sumber keuangan itu salah satunya berasal dari Pendapatan Asli Daerah (PAD), yaitu pajak daerah. Peningkatan Pendapatan Asli Daerah (PAD) merupakan tolak ukur bagi daerah dalam menyelenggarakan dan mewujudkan otonomi daerah. Pemerintah daerah selaku badan perwakilan daerah harus dapat meningkatkan Pendapatan Asli Daerah (PAD) tanpa harus bergantung pada pemerintah pusat. Pada prinsipnya semakin besar sumbangan Pendapatan Asli Daerah (PAD) terhadap Anggaran dan Pendapatan Belanja Daerah (APBD) akan menunjukkan semakin kecil ketergantungan daerah kepada pusat.

Salah satu usaha untuk meningkatkan Pendapatan Asli Daerah (PAD) yaitu dengan meningkatkan kontribusi berbagai jenis pajak yang ada di masing-masing wilayah. Usaha yang telah dilakukan oleh Pemerintah Kabupaten Purworejo adalah dengan berusaha meningkatkan realisasi pajak daerah khususnya dari sektor pajak reklame jenis billboard, spanduk, baliho, bando jalan, stiker, selebaran dan sejenisnya. Pajak reklame merupakan salah satu sumber penerimaan yang cukup besar di Kabupaten Purworejo. Pajak reklame dapat memberikan kontribusi tersendiri terhadap penerimaan Pendapatan Asli Daerah (PAD), hal ini terlihat pada penerimaan pajak reklame Kabupaten Purworejo pada tahun 2012 sebesar Rp12.707.351.362,-; 2013 sebesar Rp30.595.221.119,-; 2014 sebesar Rp34.391.112.221,-; 2015 sebesar Rp 384.726.123,-; dan tahun 2016 sebesar Rp 566.737.279,-, sehingga pemerintah daerah diharap dapat lebih mengoptimalkan objek pajak ini serta memberikan perhatian khusus dalam pengelolaannya agar Pendapatan Asli Daerah (PAD) dapat digunakan untuk membiayai kegiatan rutin pemerintahan dan membiayai pembangunan Kabupaten Purworejo.

Sebagai sumber penerimaan yang diandalkan untuk mengoptimalkan Pendapatan Asli Daerah (PAD) Kabupaten Purworejo, namun dalam prakteknya masih terdapat pelaksanaan yang kurang sesuai dengan Peraturan Daerah Kabupaten Purworejo No. 9 Tahun 2010 yang mengatur tentang Pajak Reklame. Berdasarkan hasil wawancara dengan salah satu pegawai Badan Pendapatan Pengelolaan Keuangan dan Aset Daerah (BPPKAD) Sub Bidang Penagihan dan Penerimaan, ketidaksesuaian tersebut antara lain: banyak ditemui Wajib Pajak dari luar daerah yang belum mengetahui tentang birokrasi pembayaran pajak reklame di Kabupaten Purworejo, reklame yang belum memiliki ijin, kurangnya kejelian petugas dalam proses penerimaan pajak reklame, dan jumlah personil petugas yang belum memadai.

Berdasarkan uraian tersebut di atas, peneliti tertarik untuk melakukan penelitian langsung mengenai analisis pajak reklame di Kabupaten Purworejo selama kurun waktu 2012 sampai dengan 
2016 yang dilaksanakan di Badan Pendapatan Pengelolaan Keuangan dan Aset Daerah (BPPKAD) Kabupaten Purworejo. Dari penelitian tersebut dapat diketahui seberapa besar kontribusi pajak reklame di Kabupaten Purworejo serta bagaimana kinerja Badan Pendapatan Pengelolaan Keuangan dan Aset Daerah (BPPKAD) Kabupaten Purworejo dalam proses pemungutan pajak reklame. Dengan demikian dapat diketahui berbagai kendala dalam pengoptimalan pajak reklame, sehingga dapat ditemukan berbagai solusi pelaksanaan pemungutan pajak reklame yang lebih baik agar sesuai dengan prosedur, lebih efektif dan efisien dengan tetap memperhatikan standar dan pedoman yang telah ditetapkan.

\section{Rumusan Masalah}

Berdasarkan latar belakang yang telah diuraikan di atas, maka peneliti mengemukakan pokok permasalahan sebagai berikut:

a. Seberapa besar kontribusi jenis-jenis pajak reklame terhadap Pendapatan Asli Daerah (PAD) dan Pendapatan Pajak Daerah (PPD) di Kabupaten Purworejo selama kurun waktu 2012-2016?

b. Bagaimana pertumbuhan pajak reklame di Kabupaten Purworejo selama kurun waktu 2012-2016?

c. Sejaumana kendala yang dihadapi oleh Badan Pendapatan Pengelolaan Keuangan dan Aset Daerah (BPPKAD) Kabupaten Purworejo dalam proses pemungutan pajak reklame?

d. Bagaimana upaya yang dilakukan oleh Badan Pendapatan Pengelolaan Keuangan dan Aset Daerah (BPPKAD) Kabupaten
Purworejo dalam proses optimalisasi pemungutan pajak reklame?

\section{Tujuan Penelitian}

Adapun tujuan dari penelitian ini yaitu sebagai berikut:

a. Untuk mengetahui perkembangan kontribusi berbagai jenis pajak reklame terhadap Pendapatan Asli Daerah (PAD) dan Pendapatan Pajak Daerah (PPD) Kabupaten Purworejo selama kurun waktu 2012-2016.

b. Untuk mengetahui pertumbuhan pajak reklame di Kabupaten Purworejo selama kurun waktu 2012-2016.

c. Untuk mengetahui kendala-kendala yang dihadapi oleh Badan Pendapatan Pengelolaan Keuangan dan Aset Daerah (BPPKAD) Kabupaten Purworejo dalam proses pemungutan pajak reklame.

d. Untuk mengetahui upaya-upaya yang dihadapi oleh Badan Pendapatan Pengelolaan Keuangan dan Aset Daerah (BPPKAD) Kabupaten Purworejo dalam proses pemungutan pajak reklame.

\section{Manfaat Penelitian}

Penelitian ini diharapkan dapat menjadi masukan bagi Pemerintah Daerah Purworejo terutama aparat Badan Pendapatan Pengelolaan Keuangan dan Aset Daerah (BPPKAD) Purworejo untuk meningkatkan pemungutan serta pengelolaan pajak daerah khususnya pajak reklame sebagai sumber Pendapatan Asli Daerah. 


\section{TINJAUAN PUSTAKA}

\section{Pajak}

Pengertian pajak menurut Undang-

Undang Republik Indonesia Nomor 28 Tahun 2007 Tentang Perubahan Ketiga atas Undang-Undang Nomor 6 Tahun 1983 Tentang Ketentuan Umum dan Tata Cara Perpajakan Pasal 1 Angka 1 adalah kontribusi wajib kepada negara yang terutang oleh orang pribadi atau badan yang bersifat memaksa berdasarkan Undang-Undang, dengan tidak mendapatkan imbalan secara langsung dan digunakan untuk keperluan negara bagi sebesar-besarnya kemakmuran rakyat.

Menurut Undang-Undang Nomor 28 Tahun 2009 tentang Pajak Daerah dan Retribusi Daerah Pasal 1 Angka 10 adalah Pajak Daerah yang selanjutnya disebut Pajak, adalah kontribusi wajib kepada Daerah yang terutang oleh orang pribadi atau badan yang bersifat memaksa berdasarkan Undang-Undang, dengan tidak mendapatkan imbalan secara langsung dan digunakan untuk keperluan Daerah bagi sebesar-besarnya kemakmuran rakyat. Dasar hukum pemungutan Pajak Daerah dan Retribusi Daerah adalah UndangUndang Nomor 28 Tahun 2009 tentang Pajak Daerah dan Retribusi Daerah.

\section{Pajak Reklame}

Reklame adalah benda, alat, perbuatan, atau media yang bentuk dan corak ragamnya dirancang untuk tujuan komersial memperkenalkan, menganjurkan, mempromosikan, atau untuk menarik perhatian umum, terhadap barang, jasa, orang atau badan, yang dapat dilihat, dibaca, didengar, dirasakan, dan/atau dinikmati oleh umum. Pajak reklame dilihat dari lembaga pemungutannya termasuk sebagai pajak daerah.

Pemungutan Pajak Reklame di Indonesia saat ini didasarkan pada dasar hukum yang jelas dan kuat sehingga harus dipatuhi oleh masyarakat dan pihak yang terkait. Dasar pemungutan Pajak Reklame pada suatu kabupaten atau kota (Siahaan, 2013:383) adalah sebagai berikut.

a. Undang-Undang Nomor 28 Tahun 2009 tentang Pajak Daerah dan Retribusi Daerah.

b. Undang-Undang Nomor 34 Tahun 2009 yang merupakan perubahan atas Undang-Undang Nomor 18 Tahun 1987 tentang Pajak Daerah dan Retribusi Daerah.

c. Peraturan Pemerintah Nomor 65 Tahun 2001 tentang Pajak Daerah.

d. Peraturan daerah kabupaten/kota yang mengatur tentang Pajak Reklame.

e. Keputusan bupati/walikota yang mengatur tentang Pajak Reklame sebagai aturan pelaksanaan peraturan daerah tentang Pajak Reklame pada kabupaten/kota dimaksud.

Adapun objek pajak yang dimaksud sebagai berikut:

a. Reklame papan/billboard/videotron/megatron dan sejenisnya;

b. Reklame kain;

c. Reklame melekat, stiker;

d. Reklame selebaran;

e. Reklame berjalan, termasuk pada kendaraan;

f. Reklame udara;

g. Reklame apung; 
h. Reklame suara;

i. Reklame film/slide;

j. Reklame peragaan.

Dasar Pengenaan Pajak Reklame Menurut Peraturan Daerah Kabupaten Purworejo Nomor 9 Tahun 2010 Tentang Pajak Reklame Bab IV Pasal 7, dasar pengenaan pajak reklame ditetapkan sebagai berikut.

a. Dasar pengenaan Pajak adalah nilai sewa reklame;

b. Dalam hal reklame diselenggarakan oleh pihak ketiga, nilai sewa reklame sebagaimana dimaksud pada ayat (1), ditentukan berdasarkan nilai kontrak reklame;

c. Dalam hal reklame diselenggarakan sendiri, nilai sewa reklame sebagaimana dimaksud pada ayat (1), dihitung dengan memperhatikan faktor jenis, bahan yang digunakan, lokasi penempatan, waktu, jangka waktu penyelenggaraan, jumlah, dan ukuran media Reklame; d. Dalam hal nilai sewa reklame sebagaimana dimaksud pada ayat (2) tidak diketahui dan/atau dianggap tidak wajar, nilai sewa reklame ditetapkan dengan menggunakan faktor-faktor sebagaimana dimaksud pada ayat (3);

e. Cara perhitungan nilai sewa reklame sebagaimana dimaksud pada ayat (3), ditetapkan dengan Peraturan Bupati;

f. Hasil perhitungan nilai sewa reklame sebagaimana dimaksud pada ayat (4), ditetapkan dengan Keputusan Bupati.

Tarif Pajak Reklame

Menurut Peraturan Daerah

Kabupaten Purworejo Nomor 9 Tahun 2010 Tentang Pajak Reklame Bab IV Pasal 8 , tarif pajak reklame ditetapkan sebesar 25\% (dua puluh lima persen). Cara perhitungan Nilai Sewa Reklame adalah sebagai berikut ini.

Pajak Terutang $=$ Tarif Pajak $\times$ Dasar Pengenaan Pajak

$=$ Tarif Pajak $\times$ Nilai Sewa Reklame

Pajak terutang ini dipungut di wilayah tempat Reklame tersebut diselenggarakan dengan Masa Pajak 1 (satu) bulan kalender dan Tahun Pajak adalah jangka waktu yang lamanya 1 (satu) tahun kalender.

\section{Pendapatan Asli Daerah (PAD)}

Pendapatan Asli Daerah (PAD) merupakan bagian dari pendapatan daerah yang salah satunya bersumber dari pajak. PAD ini merupakan sumber keuangan daerah yang digali dari wilayah daerah yang bersangkutan yang terdiri dari hasil pajak daerah, hasil retribusi daerah, hasil pengelolaan kekayaan daerah yang dipisahkan dan lain-lain pendapatan asli daerah yang sah. 


\section{Penelitian Terdahulu}

Penelitian sebelumnya tentang Pajak Reklame yaitu, Alfian Firmansyah (2014) tentang "Analisis Kontribusi dan Efektifitas Pemungutan Pajak Reklame untuk Meningkatkan Pendapatan Asli Daerah Kota Surabaya." Hasil dari penelitian tersebut menunjukkan bahwa nilai kontribusi pajak reklame terhadap Pendapatan Asli Daerah (PAD) Kota Surabaya dinilai masih sangat kurang yaitu kurang dari 10\%. Dari hasil perhitungan ini dapat diketahui bahwa kontribusi terbesar terjadi pada tahun 2010 yakni sebesar 9,19\% dan terendah pada tahun 2013 yakni sebesar 5,22\% sedangkan ratarata kontribusi pajak reklame adalah sebesar $6,56 \%$ yang menurut kriteria berarti sangat kurang atau rendah. Hal ini karena dalam kurun waktu 2011 hingga 2013 terjadi peningkatan signifikan dalam penerimaan pajak BPHTB yang disebabkan oleh pengalihan BPHTB dari Pemerintah Pusat kepada Pemerintah Daerah/Pemerintah Kota berdasarkan UU No.28 Tahun 2009, yang mulai diberlakukan sejak 1 Januari 2011.

Perbedaan penelitian ini dengan penelitian sebelumnya adalah pada tahun pengamatan, perbedaan wilayah atau lokasi, tujuan penelitian fokus pada kontribusi dan efektifitas pemungutan pajak reklame untuk meningkatkan pendapatan asli daerah (PAD).

\section{ANALISIS DATA DAN PEMBAHASAN}

Sistem Pemungutan Pajak di Badan Pendapatan Pengelolaan Keuangan dan Aset Daerah (BPPKAD) Purworejo yaitu official assessment system dan self assessment system. Untuk pajak reklame BPPKAD Purworejo menerapkan official assessment system. Dalam sistem tersebut memberikan kewenangan kepada pemerintah untuk menghitung besaran pajak terutang yang akan dibayar oleh wajib pajak.

1. Analisis Berbagai Jenis Pajak Reklame terhadap Pendapatan Asli Daerah (PAD) dan Pendapatan Pajak Daerah (PPD) di Kabupaten Purworejo Tahun 2012-2016.

Dengan diberlakukannya UU No. 34 Tahun 2000 tentang Pajak Daerah dan Retribusi Daerah, pemerintah daerah diberi ruang yang lebih luas untuk menarik pajak daerah dan retribusi daerah di wilayah yuridiksinya dengan mengeluarkan peraturan-peraturan daerah. Kontribusi pajak reklame terhadap PAD di Kabupaten Purworejo dihitung dengan membandingkan jumlah realisasi pajak reklame dengan jumlah PAD. Tabel 3.1 menunjukkan klasifikasi kriteria kontribusi: 
Tabel 3.1

Klasifikasi Kriteria Kontribusi

\begin{tabular}{cc}
\hline Persentase & Kriteria \\
\hline Lebih dari 50\% & Sangat Baik \\
$\mathbf{4 0 , 1 0 \%}-\mathbf{5 0 \%}$ & Baik \\
$\mathbf{3 0 , 1 0 \%}-\mathbf{4 0 \%}$ & Cukup Baik \\
$\mathbf{2 0 , 1 0 \%}-\mathbf{3 0 \%}$ & Sedang \\
$\mathbf{1 0 , 1 0 \%}-\mathbf{2 0 \%}$ & Kurang \\
$\mathbf{0 , 0 0 \%}-\mathbf{1 0 \%}$ & Sangat Kurang \\
\hline Sumber: Tim Litbang Depdagri-Fisipol UGM 1991 dalam Aulad, 2013
\end{tabular}

Sumber: Tim Litbang Depdagri-Fisipol UGM 1991 dalam Aulad, 2013

Rumus yang digunakan untuk menghitung kontribusi Pajak Reklame terhadap Pendapatan Asli Daerah (PAD), adalah sebagai berikut:

$$
\text { Kontribusi }=\frac{\text { Penerimaan Pajak Reklame }}{\text { Pendapatan Asli Daerah }} \times 100 \%
$$

Sumber: Sadono Sukirno (1985:21) (dalam Dhani Kurniawan 2000)

Berikut Tabel 3.2 yang menyajikan perbandingan antara penerimaan jenisjenis Pajak Reklame terhadap penerimaan Pendapatan Asli Daerah (PAD) tahun 2012-2016 untuk mengetahui rasio kontribusi.

Tabel 3.2

Kontribusi Berbagai Jenis Pajak Reklame Terhadap Pendapatan Asli

Daerah (PAD) di Kabupaten Purworejo Tahun 2012-2016

\begin{tabular}{clccc}
\hline Tahun & \multicolumn{1}{c}{$\begin{array}{c}\text { Jenis-Jenis Pajak } \\
\text { Reklame }\end{array}$} & $\begin{array}{c}\text { Penerimaan Pajak } \\
\text { Reklame }\end{array}$ & $\begin{array}{c}\text { Penerimaan } \\
\text { Pendapatan Asli } \\
\text { Daerah (PAD) }\end{array}$ & $\begin{array}{c}\text { Jumlah } \\
\text { Kontribusi } \\
\text { (dalam persen) }\end{array}$ \\
\hline 2012 & $\begin{array}{l}\text { Reklame Papan/ } \\
\text { Billboard/ Videotron/ } \\
\text { Megatron }\end{array}$ & Rp173.965.000 & Rp12.707.351.362 & $1,369 \%$ \\
& & & \\
\end{tabular}

JURNAL AKUNTANSI DAN PAJAK, VOL. 18, NO. 01, JULI 2017 - 164 
2012 Reklame Kain

2013 Reklame Papan/

Billboard/ Videotron/

Megatron

2013 Reklame Kain

2014 Reklame Papan/

Billboard/ Videotron/

Megatron

2014 Reklame Kain

2015 Reklame Papan/

Billboard/ Videotron/

Megatron

2015 Reklame Kain

2016 Reklame Papan/

Billboard/ Videotron/

Megatron

2016

Reklame Kain
Rp74.120.750

Rp202.370.860

Rp82.892.500

Rp218.237.250

Rp31.905.961.547

$0,259 \%$

Rp33.080.371.793

$0,659 \%$

Rp84.026.000

Rp33..080.371.793

$0,254 \%$

Rp237.559.623

Rp38.301.790.460

$0,620 \%$

Rp147.166.500

Rp38.301.790.460

$0,384 \%$

Rp365.606.464

Rp42.426.454.305

$0,861 \%$

Rp201.130.815

Rp42.426.454.305

$0,474 \%$

Sumber : BPPKAD Kabupaten Purworejo, data diolah

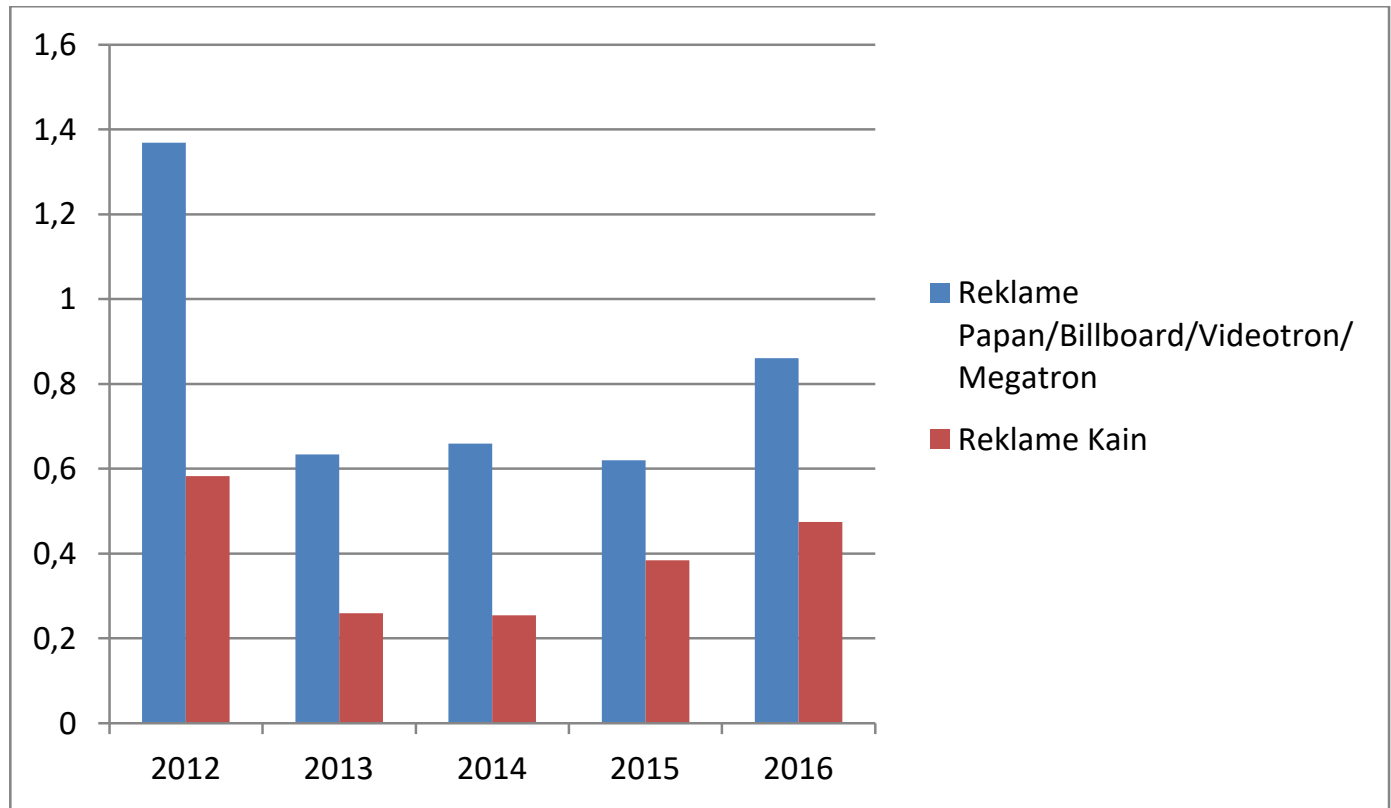

Gambar 3.1

Grafik Kontribusi Berbagai Jenis Pajak Reklame terhadap Pendapatan Asli Daerah (PAD) di Kabupaten Purworejo Tahun 2012-2016

JURNAL AKUNTANSI DAN PAJAK, VOL. 18, NO. 01, JULI 2017 - 165 
Tabel 3.2 menunjukkan bahwa besarnya kontribusi berbagai jenis pajak reklame terhadap PAD di Kabupaten Purworejo tahun 2012-2016 cukup berfluktuasi. Rata-rata kontribusi berbagai jenis pajak reklame PAD di Kabupaten Purworejo dari 2012-2016 adalah 0,609\% dan termasuk dalam kriteria sangat kurang.

Kontribusi pajak reklame, baik reklame papan/ billboard/ videotron/ megatron maupun reklame kain dari tahun 2012 sampai dengan 2016 selalu berada dalam kriteria sangat kurang. Pada tahun 2013 kontribusi reklame papan/ billboard/ videotron/ megatron dan reklame kain mengalami penurunan yang signifikan dari tahun sebelumnya. Reklame papan/ billboard/ videotron/ megatron mengalami penurunan sebesar $0,735 \%$ dari $1,369 \%$ di tahun 2012 menjadi 0,634\% di tahun 2013, dan reklame kain mengalami penurunan sebesar $0,324 \%$ dari $0,583 \%$ di tahun 2012 menjadi $0,259 \%$ di tahun 2013. Hal ini disebabkan karena pada tahun 2013 pajak bumi dan bangunan mulai ditangani oleh Pemerintah Daerah sehingga PAD mengalami peningkatan yang signifikan dan menyebabkan persentase kontribusi pada berbagai jenis pajak reklame terhadap PAD mengalami penurunan. Pada tahun 2014 terjadi penurunan lagi sebesar $0,025 \%$ dari $0,634 \%$ di tahun 2013 menjadi $0,659 \%$ di tahun 2014 untuk reklame papan/ billboard/ videotron/ megatron dan sebesar $0,005 \%$ dari $0,259 \%$ di tahun 2013 menjadi $0,254 \%$ di tahun 2014 untuk reklame kain. Penurunan ini disebabkan karena kurang optimalnya kinerja pemerintah daerah Purworejo dalam melaksanakan pemungutan dan pengelolaan pajak reklame. Pada tahun 2015 terjadi penurunan tetapi hanya di jenis reklame papan/ billboard/ videotron/ megatron yaitu sebesar $0,039 \%$ dari $0,659 \%$ di tahun 2014 menjadi $0,620 \%$ di tahun 2015, sedangkan reklame kain mengalami kenaikan sebesar $0,130 \%$ dari 0,254\% di tahun 2013 menjadi $0,384 \%$ di tahun 2015. Penurunan di tahun 2015 juga terjadi karena pemerintah belum melakukan optimalisasi pada pelaksanaan pemungutan dan pengelolaan pajak reklame. Kemudian pada tahun 2016, baik reklame papan/ billboard/ videotron/ megatron dan reklame kain mulai menunjukkan perkembangan yang bagus karena keduanya mengalami peningkatan. Reklame papan/ billboard/ videotron/ megartron meningkat sebesar $0,241 \%$ dari $0.620 \%$ di tahun 2015 menjadi $0,861 \%$ di tahun 2016 dan reklame kain meningkat sebesar $0,090 \%$ dari $0,384 \%$ di tahun 2015 menjadi 0,474\% di tahun 2016.

Dilihat dari Gambar 3.1, dari tahun 2012 sampai dengan tahun 2016 penerimaan pajak reklame selalu mengalami peningkatan. Tingkat kontribusi pajak reklame terhadap PAD menunjukkan tingat yang paling rendah pencapaiannya untuk reklame jenis papan/ billboard/ videotron/ megatron adalah tahun 2015 dan tingkat yang paling tinggi pencapaiannya adalah tahun 2012. Sedangkan untuk reklame jenis kain, tingkat yang paling rendah pencapaiannya adalah tahun 2014 dan yang paling tinggi pencapaiannya adalah tahun 2012 . 
Kontribusi pajak reklame jika di lihat dari Pendapatan Pajak Daerah (PPD) di Kabupaten Purworejo

dihitung dengan rumus perhitungan sebagai berikut:

$$
\text { Kontribusi }=\frac{\text { Penerimaan Pajak Reklame }}{\text { Pendapatan Pajak Daerah }} \times 100 \%
$$

Sumber: Sadono Sukirno (1985:21) (dalam Dhani Kurniawan 2000)

Berdasarkan tabel 3.3, besarnya kontribusi pajak reklame terhadap PPD di Kabupaten Purworejo tahun 20122016 cenderung meningkat. Rata-rata kontribusi pajak reklame terhadap PPD di Kabupaten Purworejo dari 20122016 adalah 0,620\% dan termasuk dalam kriteria sangat kurang.

Kontribusi pajak reklame baik reklame papan/ billboard/ videotron/ megatron maupun reklame kain dari tahun 2012 sampai dengan 2016 selalu berada dalam kriteria sangat kurang. Pada tahun 2013 kontribusi reklame papan/ billboard/ videotron/ megatron dan reklame kain mengalami penurunan yang signifikan dari tahun sebelumnya. Reklame papan/ billboard/ videotron/ megatron mengalami penurunan sebesar $0,8 \%$ dari $1,436 \%$ di tahun 2012 menjadi $0,636 \%$ di tahun 2013, dan reklame kain mengalami penurunan sebesar $0,351 \%$ dari $0,611 \%$ di tahun 2012 menjadi $0,260 \%$ di tahun 2013. Hal ini disebabkan karena pada tahun 2013 pajak bumi dan bangunan mulai ditangani oleh Pemerintah Daerah sehingga PPD secara keseluruhan mengalami peningkatan, meskipun sebagian tidak berasal dari
Pajak Reklame. Pada tahun 2014 terjadi penurunan lagi sebesar $0,027 \%$ dari $0,636 \%$ di tahun 2013 menjadi $0,663 \%$ di tahun 2014 untuk reklame papan/ billboard/ videotron/ megatron dan sebesar $0,005 \%$ dari $0,260 \%$ di tahun 2013 menjadi $0,255 \%$ di tahun 2014 untuk reklame kain. Penurunan ini disebabkan karena kurang optimalnya kinerja pemerintah daerah Purworejo dalam melaksanakan pemungutan dan pengelolaan pajak reklame. Pada tahun 2015 terjadi penurunan tetapi hanya di jenis reklame

papan/billboard/videotron/megatron yaitu sebesar $0,039 \%$ dari $0,663 \%$ di tahun 2014 menjadi $0,624 \%$ di tahun 2015, sedangkan reklame kain mengalami kenaikan sebesar 0,132\% dari $0,255 \%$ di tahun 2013 menjadi $0,387 \%$ di tahun 2015. Penurunan di tahun 2015 ini terjadi karena pemerintah masih belum melakukan optimalisasi pada pelaksanaan pemungutan dan pengelolaan pajak reklame. Kemudian pada tahun 2016, baik reklame papan/ billboard/ videotron/ megatron dan reklame kain mulai menunjukkan perkembangan 
yang bagus karena keduanya mengalami peningkatan. Reklame papan/ billboard/ videotron/ megartron meningkat sebesar $0,238 \%$ dari $0.624 \%$ di tahun 2015 menjadi 0,862\% di tahun 2016 dan reklame kain meningkat sebesar $0,087 \%$ dari $0,387 \%$ di tahun 2015 menjadi 0,474\% di tahun 2016. Berdasarkan penelitian yang dilakukan di BPPKAD Purworejo, peningkatan ini disebabkan karena pemerintah daerah Purworejo mulai melakukan penertiban dan penataan kembali reklame-reklame yang terpasang dan mengoreksi peraturan-peraturan tentang penyelenggaraan reklame dalam rangka peningkatan penerimaan pajak reklame. Hal ini menunjukkan bahwa pajak reklame merupakan potensi yang perlu dipertimbangkan untuk peningkatan PPD Kabupaten Purworejo.

Tabel 3.3

\begin{tabular}{clccc}
\hline \multicolumn{5}{c}{ Kontribusi Berbagai Jenis Pajak Reklame Terhadap Pendapatan Pajak Daerah } \\
(PPD) di Kabupaten Purworejo Tahun 2012-2016
\end{tabular}

Sumber: BPPKAD Kabupaten Purworejo, data diolah

Dilihat dari Gambar 3.2, dari tahun 2012 sampai dengan tahun 2016 penerimaan pajak reklame selalu mengalami peningkatan, meskipun di lihat dari sisi kontribusi masih termasuk kriteria sangat kurang. 


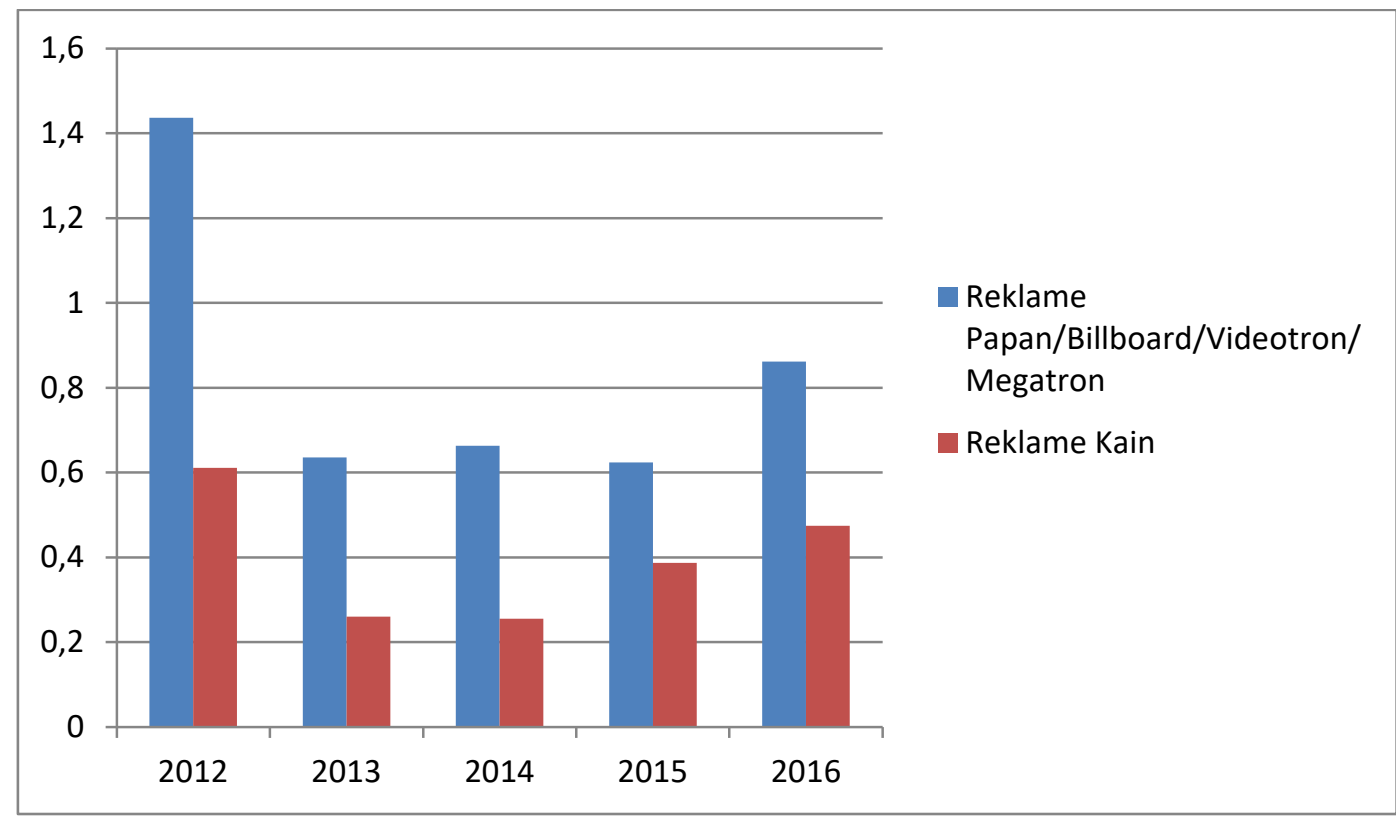

Gambar 3.2

Grafik Kontribusi Pajak Reklame terhadap Pendapatan Pajak Daerah (PPD) di Kabupaten Purworejo Tahun 2012-2016

Selama kurun waktu tahun anggaran 2012 sampai dengan tahun 2016, BPPKAD Purworejo telah memberlakukan berbagai macam pajak daerah, sesuai dengan peraturan yang berlaku. Pada setiap awal tahun anggaran, pemerintah daerah beserta DPRD dalam menyusun anggaran pendapatan dan belanja daerah menetapkan target masing-masing komponen penerimaan pajak daerah dan retribusi daerah. Secara umum, realisasi pajak daerah yang diterima oleh Pemerintah Daerah Kabupaten Purworejo cukup memuaskan. Namun kontribusi pajak dalam PAD dan PPD di Kabupaten Purworejo masih dibilang sedikit karena belum mencapai 25\% dari PAD Kabupaten Purworejo.
2. Analisis Pertumbuhan Pajak Reklame di Kabupaten Purworejo Tahun 2012-2016

Pajak Reklame dikenakan kepada setiap perusahaan atau badan lainnya yang akan memasang reklame dalam usahanya memperkenalkan produknya kepada masyarakat. Pemerintah Kabupaten Purworejo melalui BPPKAD harus memperhatikan asasasas pemungutan pajak berdasarkan pada peraturan yang berlaku termasuk pelaksaan sanksi tegas terhadap Wajib Pajak yang tidak tertib terhadap peraturan perpajakan. Perkembangan penerimaan pajak reklame di Kabupaten Purworejo dapat di lihat pada tabel 3.4.

\section{Tabel 3.4}




\section{Analisis Perkembangan Pajak Reklame di Kabupaten Purworejo}

Tahun 2012-2016

\begin{tabular}{cccc}
\hline Tahun & $\begin{array}{c}\text { Penerimaan Pajak } \\
\text { Reklame }\end{array}$ & $\begin{array}{c}\text { Perkembangan } \\
\text { (dalam rupiah) }\end{array}$ & $\begin{array}{c}\text { Perkembangan } \\
\text { (dalam persen) }\end{array}$ \\
2012 & Rp248.085.750 & - & - \\
2013 & Rp285.263.360 & Rp37.177.610 & $14,985 \%$ \\
2014 & Rp302.263.250 & Rp16.999.890 & $5,959 \%$ \\
2015 & Rp384.726.123 & Rp82.462.873 & $27,281 \%$ \\
2016 & Rp566.737.279 & Rp182.011.156 & $47,309 \%$ \\
\hline & Rata-Rata & & $19,106 \%$ \\
\hline
\end{tabular}

Sumber: BPPKAD Kabupaten Purworejo, data diolah

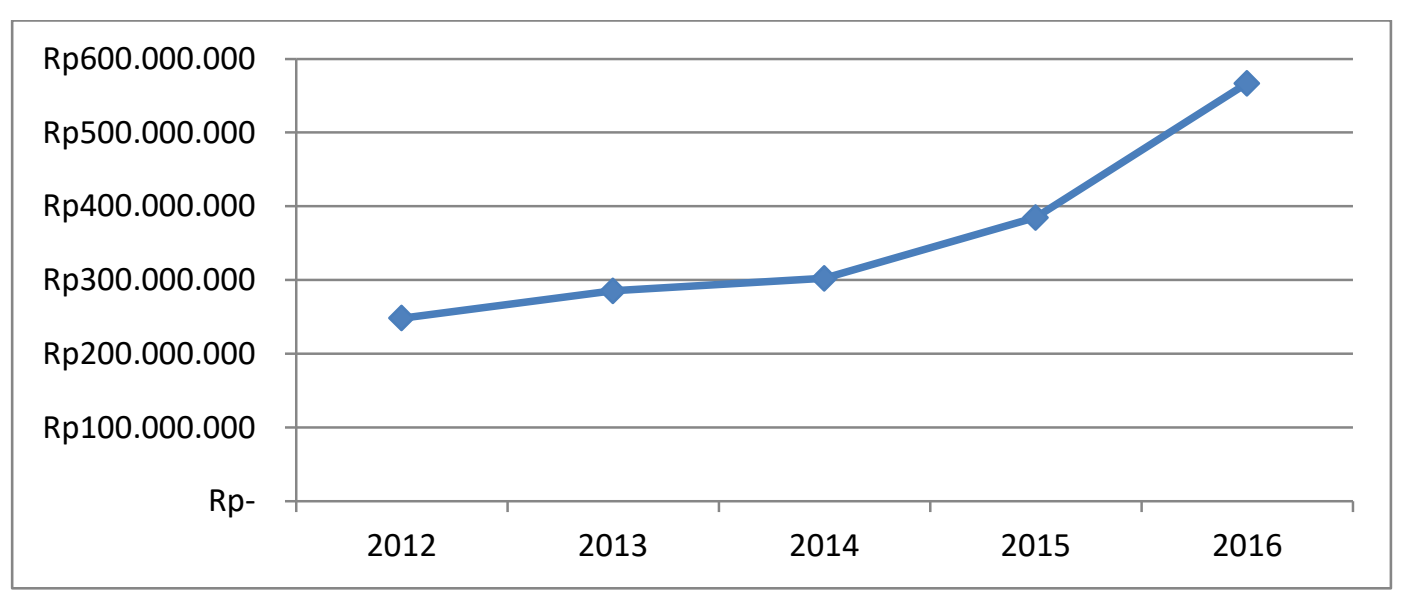

Gambar 3.3

Grafik Perkembangan Pajak Reklame di Kabupaten Purworejo

Tahun 2012-2016

3. Kendala-Kendala dalam Proses Pemungutan Pajak Reklame di Kabupaten Purworejo

Berdasarkan hasil wawancara dengan pegawai BPPKAD Kabupaten Purworejo Sub Bidang Penagihan dan Penerimaan, dalam melaksanakan pemungutan pajak reklame di Kabupaten Purworejo masih terdapat kekurangan karena adanya berbagai kendala dalam pemungutan pajak. Berbagai kendala tersebut terdiri menjadi dua hal, yaitu kendala internal dan kendala eksternal.

Kendala-kendala eksternal diantaranya banyak ditemui Wajib Pajak dari luar daerah yang belum mengetahui tentang birokrasi JURNAL AKUNTANSI DAN PAJAK, VOL. 18, NO. 01, JULI 2017 - 170 
pembayaran pajak reklame dikarenakan ijin pemasangan reklame dikeluarkan dari kantor Dinas Penanaman Modal dan Pelayanan Satu Pintu (DPMPSP) sedangkan khusus pajak reklame pembayarannya di BPPKAD; dan masih banyak ditemukan reklame yang belum memiliki ijin dikarenakan Wajib Pajak tidak mengetahui kalau reklame tersebut dikenai pajak. Hal ini disebabkan karena belum dilakukan sosialisasi secara optimal kepada Wajib Pajak oleh petugas dari Badan BPPKAD.

Kendala-kendala internal penerimaan pajak reklame diantaranya belum memenuhi target penerimaan pajak disebabkan karena kurangnya kejelian petugas dalam proses penerimaan pajak reklame; dan jumlah personil pertugas yang belum memadai untuk mengawasi reklame yang terpasang di wilayah Purworejo.

Berdasarkan hasil wawancara di atas dapat disimpulkan bahwa kendala yang seringkali dihadapi oleh BPPKAD Kabupaten Purworejo Sub Bidang Penagihan dan Penerimaan adalah kurangnya peran aktif pihak BPPKAD Kabupaten Purworejo dalam melakukan sosialisasi mengenai pajak reklame kepada masyarakat sehingga menyebabkan kurangnya kesadaran wajib pajak dalam melaksanakan kewajiban perpajakannya. Selain itu kecukupan atas sumber daya manusia juga perlu dipertimbangkan. Hal ini tentu dapat memberikan pengaruh terhadap pencapaian target penerimaan pajak reklame yang telah ditetapkan oleh BPPKAD Kabupaten Purworejo sehingga nantinya akan berdampak pada kontribusi pajak daerah terhadap PAD.

\section{Upaya Peningkatan Pajak Reklame di Kabupaten Purworejo}

Berdasarkan kendala-kendala yang dihadapi, maka BPPKAD Kabupaten Purworejo melakukan program kerja operasional yang dilaksanakan dengan tujuan agar dapat terealisasi sesuai dengan target yang telah ditetapkan. Upaya-upaya yang dilakukan BPPKAD Kabupaten Purworejo antara lain:

a. Melakukan pendataan aktif dan pasif. Pendataan aktif dilakukan dengan cara petugas pajak mendatangi langsung Wajib Pajak yang bersangkutan. Sedangkan pendataan pasif dilakukan dengan cara Wajib Pajak datang sendiri ke Kantor Pelayanan Pajak;

b. Melakukan peningkatan pelayanan untuk memberikan keyakinan serta meningkatkan kesadaran Wajib Pajak;

c. Melakukan penagihan pajak secara langsung kepada Wajib Pajak; dan

d. Melakukan penertiban dengan mekanisme menemui langsung Wajib Pajak yang bersangkutan oleh petugas pemungut apabila ditemukan reklame tidak berijin atau reklame berijin tetapi Wajib Pajak belum melakukan pembayaran pajak reklame sampai dengan batas waktu yang ditentukan. 


\section{KESIMPULAN}

Berdasarkan hasil penelitian dan pembahasan yang telah dilakukan mengenai tingkat kontribusi pajak reklame terhadap PAD dan PPD Kabupaten Purworejo maka dapat disimpulkan bahwa kontribusi penerimaan pajak reklame terhadap PAD Kabupaten Purworejo selama 5 tahun masih termasuk dalam kriteria sangat kurang dengan rata-rata 0,609\%. Sedangkan kontribusi penerimaan pajak reklame terhadap PPD dengan ratarata $0,620 \%$. Hasil tersebut berarti bahwa pengelolaan Pajak Reklame perlu diperhatikan agar bisa optimal.

Berbagai kendala yang dihadapi pihak BPPKAD Kabupaten Purworejo dalam proses pemungutan pajak reklame diantaranya masih banyak Wajib Pajak dari luar daerah yang belum mengetahui tentang birokrasi pembayaran pajak reklame; masih ditemukan reklame yang belum memiliki ijin; kurangnya kejelian petugas dalam proses penerimaan pajak reklame; dan jumlah personil petugas yang belum memadai perlu dijadikan pertimbangan untuk period ke depannya.

\section{Saran}

Berdasarkan penelitian yang telah dilakukan, maka beberapa saran yang dapat diberikan oleh peneliti yaitu: (a) perlu dilakukan pendataan ulang terhadap objek pajak reklame yang sudah ada agar potensi-potensi baru atas pajak reklame dapat terdata dengan baik; (b) mengoptimalkan potensi-potensi baru yang belum tergali oleh BPPKAD Kabupaten Purworejo agar dapat memaksimalkan pendapatan pajak reklame; (c) perlu dilakukan sosialisasi secara rutin dan merata kepada wajib pajak tentang pentingnya pajak reklame untuk menunjang kesejahteraan masyarakat, (d) perlu kiranya BPPKAD Kabupaten Purworejo memberikan sanksi yang tegas terhadap wajib pajak yang kurang disiplin dalam melaksanakan kewajiban perpajakannya; dan (e) perlu dilakukan penambahan petugas pemungut pajak yang kompeten agar proses pemungutan pajak dapat berjalan dengan lancar dan terorganisir.

\section{DAFTAR PUSTAKA}

Republik Indonesia, (2010), Peraturan Daerah Kabupaten Purworejo Nomor 9 Tahun 2010 tentang Pajak Reklame, Sekretariat Daerah Kabupaten Purworejo, Purworejo.

Republik Indonesia. (2009).Peraturan Bupati Kabupaten Purworejo Nomor 54 Tahun 2009 tentang Tata Cara Pelayanan dan Penerbitan Izin Penyelenggaraan Reklame. Sekretariat Daerah Kabupaten Purworejo. Purworejo.

Republik Indonesia. (2004).UndangUndang Nomor 32 Tahun 2004 tentang Pemerintahan Daerah. Sekretariat Negara. Jakarta. 
Republik Indonesia. (2007).UndangUndang Nomor 28 Tahun 2007 tentang Perubahan Ketiga Atas Undang-Undang Nomor 6 Tahun 1983 tentang Ketentuan Umum dan Tata Cara Perpajakan. Sekretariat Negara. Jakarta.

Republik Indonesia. (2009).UndangUndang Nomor 28 Tahun 2009 tentang Pajak Daerah dan Retribusi Daerah. Sekretariat Negara. Jakarta.

Republik Indonesia. (1945). UndangUndang Dasar Negara Republik Indonesia Tahun 1945. Sekretariat Negara. Jakarta.

Brotodiharjo, R Santoso. 2013. Pengantar Ilmu Hukum Pajak. Refika Aditama.

Firmansyah, Alfian. 2014. Analisis Kontribusi dan Efektifitas Pemungutan Pajak Reklame untuk Meningkatkan Pendapatan Asli Daerah Kota Surabaya. Jurnal Mahasiswa UNESA.

Mardiasmo. 2013. Perpajakan Edisi Revisi. Yogyakarta: Andi Offset.

Prakosa. 2005. Pajak dan Retribusi Daerah Edisi Revisi. Yogyakarta: UII Press.
Sukirno, Sadono. 1985. Ekonomi Pembangunan: Proses, Masalah, dan Dasar Kebijaksanaan. Jakarta: LPEFUI Bima Grafika. 